\title{
PERBANDINGAN EKONOMI ISLAM DAN EKONOMI KAPITALIS
}

\author{
Moch. Bukhori Muslim*
}

\begin{abstract}
The Comparation Between Islamic Economic and Capitalist Economic. The greatness of the capitalist economic theory has been questioned by many prominent economists. Due to the economic crisis occurred throughout history, it is necessary to bring out an alternative economic theory. Economic theory aspired is an economic system that is able to create justice and the welfare accompanied with blessing the world and the here after. Therefore, islamic economic theory can be considered as a way out to solve the contemporary economy problems. This article compare the system of islamic economic and the capitalist economic taking into account the philosophy, investment, distribution, theory of macro and micro aspects.
\end{abstract}

Keywords: crisis, inflation, justice, development, equality

Abstrak: Perbandingan Ekonomi Islam dan Ekonomi Kapitalis. Kehebatan teori ekonomi kapitalis sudah mulai dipertanyakan oleh banyak ekonom. Oleh karena krisis ekonomi selalu terjadi sepanjang sejarah, maka diperlukan teori ekonomi alternatif. Teori ekonomi yang dicita-citakan adalah sebuah sistem ekonomi yang mampu menciptakan keadilan dan kesejahteraan bersama, diiringi oleh konsep keberkahan dunia dan akhirat. Inilah teori ekonomi Islam yang akan membawa keadilan dan kesejahteraan menyeluruh. Ekonomi Islam dianggap sebagai jalan keluar untuk mengatasi persoalan ekonomi kontemporer. Dalam artikel ini akan dibandingkan antara sistem ekonomi Islam dengan sistem ekonomi kapitalis baik dari segi filosofis, investasi, distribusi, teori makro, maupun aspek mikronya.

Kata Kunci: krisis, inflasi, keadilan, pembangunan dan kesamaan

Naskah diterima: 3 Januari 2012, direvisi: 13 Maret 2012, disetujui: 22 Maret 2012.

* Fakultas Syariah dan Hukum UIN Syarif Hidayatullah Jakarta. Jl. Ir H. Juanda 95, Ciputat, Jakarta. E-mail: mochmuslim@yahoo.com 


\section{Pendahuluan}

Di antara dua teori ekonomi yang menonjol, teori ekonomi kapitalis masih dianggap sebagai teori yang paling kuat saat ini di dunia, karena teori ekonomi sosialis sudah dianggap tidak ada seiring runtuhnya Uni Soviet. Teori kapitalisme yang muncul dari Barat menjadi tumpuan hampir di seluruh negara saat ini telah menimbulkan ketidakadilan ekonomi, karena hanya menguntungkan Barat melalui hegemoni mata uang kertas dan sistem pinjaman ribawi. ${ }^{1}$ Bahkan kedua teori, baik kapitalis murni maupun sosialis murni dianggap sudah tidak mampu berkembang. ${ }^{2}$

Kedua aliran yang sama-sama ekstrem tersebut sudah tidak mampu lagi berkembang. Teori kapitalis yang tumpuan utama dalam aktivitas ekonominya adalah ditentukan oleh individu. Sedangkan sosialis bertumpu pada kekuasaan pemerintah. Kemudian muncul teori ketiga yang dimunculkan oleh Keynes, di mana perekonomian tidak semua diserahkan pada pasar, namun diperlukan campur tangan negara dalam batas-batas tertentu.

Saat ini, sistem perdagangan dan moneter dunia mengalami kebekuan. Sistem moneter dan perdagangan dunia telah menimbulkan pelbagai permasalahan, seperti terjadinya inflasi, menurunnya nilai daya beli uang, ketimpangan ekonomi, risiko nilai tukar dalam perdagangan internasional dan penguasaan perekonomian dunia oleh negara-negara maju khususnya negara yang memiliki nilai tukar mata uang yang kuat. ${ }^{3}$ Inflasi meredistribusikan pendapatan ke atas sehingga mereduksi keadilan sosio-ekonomi. Sebenarnya, ini saja sudah cukup dengan tidak memberikan waktu istirahat untuk berpikir bagi ekonom pembangunan. Namun, masih ada lagi dampak buruknya pada pembangunan dan akan terus begitu untuk beberapa waktu di masa yang akan datang.

Kehebatan teori ekonomi kapitalis sudah mulai dipertanyakan oleh banyak tokoh ekonom. Sepanjang abad XX telah terjadi lebih dari dua puluh krisis di sektor finansial dan beberapa dekade terakhir kekerapannya semakin tinggi.

1 Euis Amalia, Sejarah Pemikiran Ekonomi Islam dari Masa Klasik Hingga Kontemporer, (Jakarta: Pustaka Asatruss, 2005), cet. 1, h. 4.

${ }^{2}$ Sri-Edi Swasono, Ekspose Ekonomi Mewaspadai Globalisasi dan Pasar-Bebas, (Yogyakarta: Pusat Studi Ekonomi Pancasila (Pustep)-UGM, 2010), h. 47. Hal yang senada juga dikemukan oleh Anwar Abbas dalam kuliah Filsafat Sistem Ekonomi Islam di SPs UIN Syarif Hidayatullah Jakarta, 14 Maret 2012.

${ }^{3}$ M. Luthfi Hamidi, Gold Dinar Sistem Moneter Global yang Stabil dan Berkeadilan, (Jakarta: Senayan Abadi Publishing, 2007), Cet. 1, h. 31. 
Berikut ini tabel krisis yang terjadi di belahan dunia selama abad $20 .^{4}$

Tabel 1

Krisis di Beberapa Negara

\begin{tabular}{ccl}
\hline No & Tahun & \multicolumn{1}{c}{ Negara yang Mengalami Krisis } \\
\hline 1 & 1920 & Jepang mengalami depresi ekonomi \\
\hline 2 & $1922-1923$ & Jerman mengalami hyperinflasi \\
\hline 3 & 1927 & Jepang kembali mengalami krisis (37 bank ditutup) \\
\hline 4 & 1931 & Austria mengalami krisi perbankan \\
\hline 5 & 1944 & $\begin{array}{l}\text { Prancis dan Hungaria mengalami hyperinflasi } \\
\text { dan krisis moneter }\end{array}$ \\
\hline 6 & 1945 & Jerman mengalami hyperinflasi \\
\hline 7 & $1973-1974$ & Ingrris mengalami krisis perbankan \\
\hline 8 & 1982 & Krisis utang di Mexico, Argentina, Brazil, dan Venezuela \\
\hline 10 & 1980 & Krisis utang di Polandia \\
\hline 11 & 1987 & The great crash di US \\
\hline 12 & 1994 & Mexico mengalami krisis akibat kebijakan finansial yang tidak tepat \\
\hline 13 & 1997 & $\begin{array}{l}\text { Krisis keuangan di Asia Tenggara: Thailand, } \\
\text { Malaysia, dan Indonesia }\end{array}$ \\
\hline 14 & 1999 & Krisis keuangan di Korea dan Rusia \\
\hline 15 & 2011 & Krisis keuangan di Brazil dan Argentina \\
\hline
\end{tabular}

Ketergantungan yang begitu besar pada bank-bank multinasional untuk pinjaman eksternal, yang pada mulanya dijustifikasi atas dasar ketidakmampuan mengembalikan pinjaman oleh pengutang, telah meningkatkan beban utang pada tingkat yang tidak dapat dipikul lagi. Sehingga, ketidakmampuan negaranegara pengutang untuk membayar cicilan utangnya telah mengancam sendisendi kehidupan bank-bank ini. Bahkan, proses pembangunan kini terancam berantakan. Laju riil pertumbuhan juga turun. Segala usaha untuk mengurangi inflasi dan ketidakseimbangan eksternal guna meningkatkan pertumbuhan telah dipikirkan solusinya, namun hal itu belum ditemukan jalan keluarnya. ${ }^{5}$

Bagi Indonesia, krisis ekonomi 1997 berdampak sangat besar, yang pada

${ }^{4}$ Veithzal Rivai, Prospek Lembaga Keuangan Islam di Era Krisis Financial Global "Dengan Melaksanakan Sistem Keuangan Islam pada Kekuatan Bisnis \& Pelayanannya dapat Mengatasi Dampak Krisis Finansial Global, Jakarta, 30 Maret 2009, h. 3. Sumber lain dari website SS FEUI, Penyebab Krisis Eropa, 20 Desember 2011, diakses pada 12 Juni 2012.

${ }^{5}$ M. Umer Chapra, Islam dan Tantangan Ekonomi, (Jakarta: Gema Insani Press, 2000), h. 166167. 
akhirnya mengakibatkan menurunnya kualitas kesejahteraan tiap warga negara. Ini disebabkan sektor moneter tidak pernah dan tidak akan pernah lepas kaitan dengan sektor riil. Karena bagaimanapun keberadaan sektor moneter dengan segala kebijakan dan pelbagai lembaga keuangan yang menopangnya tidak bisa berdiri sendiri. Sehebat dan secanggih apapun sektor ini, pada dasarnya merupakan fasilitator bagi sektor riil. Pada saat itu Indonesia benar-benar terpuruk ke dalam krisis yang belum pernah terjadi sebelumnya. ${ }^{6}$

Ketidakseimbangan antara sektor riil dan moneter yang terjadi dipicu oleh maraknya bisnis spekulasi pada kedua pasar keuangan di atas, yaitu di pasar modal dan pasar valas sehingga terjadi fenomena yang disebut balon ekonomi (bubble economy). Bublle economy adalah sebuah ekonomi yang besar dalam perhitungan kuantitas moneternya, namun tidak diimbangi oleh sektor riil, bahkan sektor riil tersebut amat jauh ketinggalan perkembangannya. Sebelum krisis moneter Asia, dalam satu hari, dana yang gentayangan dalam transaksi maya di pasar modal dan pasar uang dunia, diperkirakan rata-rata beredar sekitar 2-3 triliun dolar AS atau dalam satu tahun sekitar 700 triliun dolar AS. Padahal arus perdagangan barang secara international dalam satu tahunnya hanya berkisar 7 triliun dolar AS. Jadi, arus uang 100 kali lebih cepat dibandingkan dengan arus barang. ${ }^{?}$

Pembangunan ekonomi di Indonesia terus diupayakan agar terbebas dari belenggu krisis. Namun demikian upaya tersebut belum nampak berhasil secara menyeluruh. Sri Edi Swasono menyatakan bahwa pembangunan yang diupayakan oleh pemerintah Indonesia bukan menggusur kemiskinan namun justru menggusur orang miskin. Pembangunan dianggap tidak mampu menciptakan keadilan dan kesejarteraan rakyat. ${ }^{8}$ Teori-teori ekonomi yang ditawarkan oleh para ahli tidak mampu menciptakan tatanan ekonomi masyarakat yang berkeadilan dan berkeadaban. Bahkan menciptakan dikotomi antara kepentingan individu, masyarakat, negara serta hubungan antar negara. Selain itu juga tidak mampu menjaga kelestarian sumber daya alam. ${ }^{9}$

${ }^{6}$ Sri-Edi Swasono, Ekspose Ekonomi Mewaspadai Globalisasi dan Pasar-Bebas, (Yogyakarta: Pusat Studi Ekonomi Pancasila (Pustep)-UGM, 2010), h. vi.

${ }^{7}$ VeithzalRivai, "Prospek Lembaga Keuangan Islam di Era Krisis Financial Global "Dengan Melaksanakan Sistem Keuangan Islam pada Kekuatan Bisnis \& Pelayanannya dapat Mengatasi Dampak Krisis Finansial Global", Jakarta, 30 Maret 2009, h. 5.

${ }^{8}$ Sri-Edi Swasono, Paradigma Baru ilmu Ekonomi, Jakarta, 28 Februari 2012, h. 1.

${ }^{9} \mathrm{M}$. Umer Chapra, Islam dan Tantangan Ekonomi, h. 1-2. Hal senada juga dikemukan A. Riawan Amin, Menata Perbankan di Indonesia, (Jakarta: UIN Press, 2009), cet.1, h. 5. 
Karena kondisi yang semacam itu, maka diperlukan teori ekonomi alternatif sebagai pengganti teori ekonomi kapitalis yang dianggap sudah mulai redup. Teori ekonomi yang dicita-citakan adalah sebuah sistem ekonomi yang mampu menciptakan keadilan dan kesejahteraan bersama yang diiringi dengan keberkahan dunia dan akhirat. ${ }^{10}$ Teori tersebut adalah ekonomi Islam yang akan membawa keadilan dan kesejahteraan bukan hanya umat Islam namun juga seluruh umat manusia, karena Islam adalah rahmat bagi seluruh alam. Artikel ini akan membandingkan sistem Islam dengan sistem ekonomi kapitalis, baik dari filosofi, investasi, distribusi, teori makro, dan aspek mikronya.

\section{Aspek Filosofi}

Teori-teori ekonomi muncul karena ketidakseimbangan antara tersedianya sumberdaya dan keinginan manusia. Kesejahteraan dan eksistensi manusia di dunia menuntut agar mencari solusi dari persoalan tersebut. Maka muncul pelbagai macam teori ekonomi, seperti teori kapitalis dan teori ekonomi Islam.

Dari aspek filosofi kedua teori ini pasti memiliki perbedaan. Sumber hukum ekonomi Islam adalah Alquran dan Hadis. Alquran dan Hadis memiliki nilai universal yang tidak hanya berisi kaidah ekonomi namun segenap dimensi kehidupan manusia. Sedangkan ekonomi kapitalis sumber hukumnya adalah the wealth of nation, the general theory, dan buku-buku pendukungnya. Ilmu ekonomi kapitalis tidak didasarkan atas wahyu. Ilmu kapitalis dipengaruhi oleh asumsi-asumsi pemikirnya. Sedangkan asumsi-asumsi pemikirnya dipengaruhi oleh latar belakang kehidupan yang memengaruhi maindset berpikirnya. Sistem ini hanya bisa dipahami secara sempurna jika memahami lingkungan situasi di mana teori ini muncul. ${ }^{11}$ Demikian juga dasar pemikiran sosialis murni yang bertumpu pada kekuasaan, di mana segala aktivitas ekonomi diatur secara penuh oleh negara, merupakan hasil pikiran manusia yang bukan merupakan ilham dari wahyu.

Dasar pemikiran ekonomi Islam dilhami dari Alquran dan Hadis yang berasal dari wahyu Allah Swt., sedangkan teori ekonomi kapitalis adalah hasil pemikiran manusia. Maka kedua sistem ini pasti berbeda. Walaupun ada yang menganggap bahwa urusan ekonomi adalah urusan dunia yang diserahkan

${ }^{10}$ Islam mengajarkan agar kita mampu menciptakan kesejahteraan yang diiringi dengan

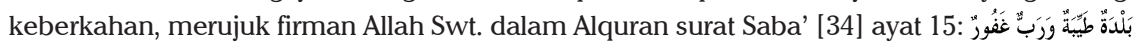

${ }^{11}$ Teori ekonomi juga disebut dengan mazhab ekonomi. Lihat, Ahmad Muhammad al-Assal dan Fathî Ahmad 'Abd al-Karîm, Sistem, Prinsip, dan tujuan Ekonomi Islam, alih bahasa Imam Saefuddin, (Jakarta: CV. Pustaka Setia, 1999), Cet. I, h. 14-17. 
kepada manusia, namun kebebasan manusia untuk menciptakan peradaban ekonomi yang baik tentu tidak boleh melanggar pokok-pokok aturan dari Allah Swt.

Karena sumbernya adalah wahyu maka segala aktivitas ekonomi Islam harus bersifat pengabdian kepada Allah Swt.. Hal itu berbeda dari kegiatan ekonomi dalam sistem yang dihasilkan oleh pemikiran manusia. Teori kapitalis sangat mendewakan individualisme. Sehingga teori ini menonjolkan rasionalisme dan materialisme. Yang menjadi pedoman ajarannya adalah bebas berbuat dan bebas bertindak. ${ }^{12}$ Teori kapitalis mengajarkan bahwa kesuksesan ekonomi ditentukan oleh diri sendiri atau disebut anthropocentrism indivi-dualism. ${ }^{13}$

Sedangkan konsep dalam teori ekonomi Islam adalah kalau manusia mau sukses, maka dia harus berusaha untuk mendapatkan karunia dari Dzat Yang Mahakuasa dan Maha Penentu. Oleh karena itu dalam Islam yang menjadi penentu bagi berhasil atau tidaknya seseorang, hal itu tidak bisa terlepas dan dilepaskan kaitannya dengan kehendak-Nya. Manusia di muka bumi adalah sebagai khalifah, maka tidak boleh terlepas dari aturan yang menjadikannya khalifah. Demikian juga dalam hal mencari dan mengumpulkan harta, teori kapitalis tidak membatasi cara manusia untuk mengumpulkan harta, namun Islam membatasinya dengan jalan yang baik dan tidak melanggar aturan-aturan Allah Swt.. Dalam bisnis Islam dilarang gharar, maysir, najsy, dan barang haram namun dalam konsep kapitalis tidak ada aturan yang ditetapkan. Karena tujuan utamanya adalah kepuasan individual.

Teori kapitalis mengajarkan bahwa harta yang sudah diperoleh mutlak menjadi hak milik pribadi. Karena mendapatkannya dari usaha sendiri maka untuk menggunakannya juga bebas atas kemaunnya sendiri. Sedangkan Islam mengajarkan bahwa pemilik mutlak harta adalah Allah Swt., manusia hanyalah sebagai pemegang amanah untuk mengelola dan memanfaatkan untuk kesejahteraan bersama. hak milik dalam ekonomi Islam terikat dengan aturan yang ditetapkan oleh syariat. Jadi kepemikan dalam Islam tidaklah mutlak namun nisbi. Jika kita merujuk kepada nas Alquran yang menyatakan bahwa semua yang ada dilangit dan bumi adalah milik Allah Swt., ${ }^{14}$ maka kita bisa menyimpulkan bahwa semua harta bahkan kita sendiri adalah milik Allah. Jika seluruh harta adalah milik Allah, maka manusia hanyalah diberi mandat untuk

\footnotetext{
${ }^{12}$ Andullah Zaky Al Kaaf, Ekonomi dalam Perspektif Islam, (Bandung: Penerbit Pusataka Setia Bandung, 2002), Cet. I, h. 40.

${ }^{13}$ Anwar Abbas, Philopsopy Sistem Ekonomi Islam, Jakarta, 14 Maret 2012, h. 3.

${ }^{14}$ Allah berfirman dalam Q.s. Thâhâ [20] ayat 6 .
} 
menggunakan dan memanfaatkan saja. Sebagai khalifah di muka bumi, maka manusia terikat dengan ketentuan yang ditetapkan Allah. Allah Swt. telah memberikan kuasa kepada manusia untuk memanfaatkannya. ${ }^{15} \mathrm{Hal}$ ini bukan berarti bahwa Islam tidak mengakui hak milik kekayaan, namun hak milik tersebut tersebut terikat oleh aturan-aturan untuk kepentingan orang banyak dan tidak membahayakan orang lain. ${ }^{16}$

Hak kepemilikan menurut Islam ada dua macam. Pertama, hak milik khusus. Manusia diciptakan Allah Swt. dengan fitrah untuk senang pada kekayaan. Dari fitrah inilah manusia memiliki hak milik atas kekayaan. Misalnya seperti dalam surah al-Fajr [89] ayat 19-20. Dalam ayat tersebut Allah menyindir bahwa manusia sangat mencintai harta dengan berlebihan. ${ }^{17}$ Kedua, hak milik umum atau hak milik orang banyak, yaitu harta yang dimanfaatkan untuk kepentingan bersama, seperti jalan, sungai, tambang, dan sumber minyak. Semua jenis harta ini harus dikuasai negara dan dimanfaatkan untuk kepentingan bersama. ${ }^{18}$ Pendapat ini didasarkan pada sebuah Hadis Rasulullah yang diriwayatkan oleh Imam Abû Dâwud:

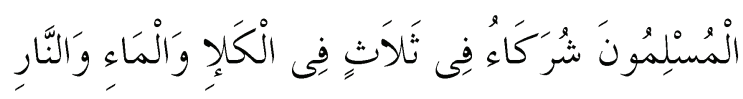

Semua orang Islam berserikat dalam tiga hal: dalam hal air, rumput, dan api. (H.r. Abî Dâwud) ${ }^{19}$

Paradigma teori ekonomi kapitalis adalah kebebasan individu sehingga instrument atau alat yang mereka junjung tinggi untuk tegaknya nilai-nilai kebebasan dan kepemilikan individual tersebutadalah mekanisme pasar bebas. Hal ini berarti bahwa pemerintah tidak boleh ikut campur dalam hal pasar. Sedangkan dalam teori ekonomi Islam mengenalkan sebuah lembaga yang bernama hisbah. Yaitu sebuah lembaga pemerintah yang berkewajiban meng-

${ }^{15}$ Allah berfirman dalam Q.s. al-Hadîd [57] ayat 7.

${ }^{16}$ Konsep pemilik absolut harta adalah Allah, sebagai firman Allah dalam surah Thâhâ [20]: 6 . Konsep hak milik dalam Islam, lihat Ahmad Muhammad al-Assal dan Fathî Ahmad 'Abd al-Karîm, Sistem, Prinsip, dan Tujuan Ekonomi Islam, alih bahasa Imam Saefuddin, (Jakarta: CV Pustaka Setia, 1999), Cet. I, h. 40-47.

${ }^{17}$ Ahmad Muhammad al-Assal dan Fathî Ahmad 'Abd al-Karîm, Sistem, Prinsip, dan Tujuan Ekonomi Islam, h. 47-52.

${ }^{18}$ Ahmad Muhammad al-Assal dan Fathî Ahmad 'Abd al-Karîm, Sistem, Prinsip, dan Tujuan Ekonomi Islam, h. 67-73.

${ }^{19}$ Abû Dâwud, Sunan Abî Dâwud, (Bayrût: Dâr al-Kitâb al-'Arabî, t.th.), Jilid III, h. 295. 
awasi kebijakan pasar agar tetap berjalan untuk kemaslahatan umat bukan hanya untuk segelintir orang. ${ }^{20}$

Dalam aspek investasi, teori ekonomi kapitalis meletakkan dasar investasinya pada riba atau interest. Di mana akibat yang muncul dari sistem ini adalah banyaknya spekulasi dan tidak terkait dengan sektor riil dengan sektor keuangan. Sehingga banyak uang beredar di dunia maya, justru tidak beredar di sektor riil. Sedangkan teori ekonomi Islam mengaharamkan riba dan menggantinya dengan sistem bagi hasil. Di mana sistem ini tidak akan menzalimi pihak lain dalam berbisnis.

Dalam teori ekonomi Islam, kekayaan harus distribusikan secara adil dan merata. Islam sangat mengecam harta hanya bergulir di kalangan orang-orang borjuis. ${ }^{21}$ Islam menentang konsep "yang kaya makin kaya, yang miskin makin miskin" yang menjadi jargon ekonomi kapitalis. Walaupun ekonomi kapitalis memiliki konsep pendistribusian harta melalui konsep pajak, namun konsep tersebut terbukti menzalami banyak orang. Islam telah memberikan solusi untuk mendistribusikan kekayaan tersebut dengan banyak jalan, yaitu zakat, infak, sedekah, wakaf, dan hibah. Konsep yang ditawarkan Islam ini lebih adil dan tidak menzalimi orang lain.

\section{Aspek Sejarah}

Ekonomi Islam telah dipraktikkan oleh Rasulullah Saw. (569-632 M) bersama masyarakat Mekah dan Madinah, kemudian dilanjutkan oleh al-Khulafâ' alRâsyidûn yang membangun pemerintahan selama 29 tahun, dari 632-661 Masehi. Kemudian terus dipraktikkan hingga kejaayaan Islam di Turki. Sejarah pemikiran ekonomi Islam telah menciptakan peradaban besar. Teori-teori ekonomi mulai dari kebijakan fiskal, kebijakan moneter, pengelolaan anggaran negara hingga mekanisme pasar telah dipraktikkan sejak zaman Rasulullah Saw. hingga masa kejayaan Islam di Turki. ${ }^{22}$

Tokoh-tokoh pemikir ekonomi antara lain adalah Abû Yûsuf (182/798). Dia telah menggagas teori kebijakan fiskal, keuangan publik, hingga mekanisme

${ }^{20}$ Peranan, sistem dan tugas lembaga hisbah lebih luas lihat Surtahman Kastin Hasan dan Sanep Ahmad, Ekonomi Islam, (Selangor: Dawama Sdn. Bhd, 2005), Edisi 2, Cet. I, h. 198-199. Lihat, juga Dede Abdul Fattah, Pasar dan Keadilan dalam Perspektif Ekonomi Islam (Analisis Peran Lembaga Hisbah Era Abbasiyah, (Jakarta: Gaung Persada Press, 2011), h. 94-95.

${ }^{21}$ Islam mengajarkan bahwa harta harus berputar dikalangan orang-orang saja (Q.s. al-Hasyr [59]: 7).

${ }^{22}$ Euis Amalia, Sejarah Pemikiran Ekonomi Islam dari Masa Klasik Hingga Kontemporer, (Jakarta: Pustaka Asatruss, 2005), h. 16-61. 
pasar. ${ }^{23}$ Imam Yahyâ Ibn 'Umar (213-289H), seorang tokoh ekonom yang mengupas masalah penetapan harga dan penimbunan. ${ }^{24}$ Imam Ghazâlî (450-505 $\mathrm{H})$, ulama besar yang mengungkap persoalan mata uang, pasar, dan pajak. ${ }^{25} \mathrm{Ada}$ juga Ibn Khaldûn (732-808 H), seorang ulama besar yang banyak mengkaji tentang pengangguran, keuangan publik, hingga perdagangan internasional. ${ }^{26}$ Masih banyak lagi ulama-ulama yang berkontribusi dalam bidang ekonomi, sehingga menopang kebangkitan peradaban Islam masa lalu.

Sedangkan teori ekonomi kapitalis diciptakan oleh Adam Smith pada tahun $1776 \mathrm{M}$. Tentu masa itu jauh setelah munculnya para ekonom muslim yang mampu melampaui zamannya. Mereka telah mengungkapkan ide-ide besar untuk mengatasi segala persoalan ekonomi yang muncul di masyarakat. Apalagi dibandingkan dengan teori ekonomi sosialis. Tentu Islam lebih dahulu dan lebih mampu menyelesaikan persoalan ekonomi, karena teori ekonomi sosialis sudah dianggap runtuh seiring runtuhnya Uni Soviet.

\section{Aspek Mekanisme Pasar}

Dalam teori ekonomi kapitralis mekanisme pasar didasarkan pada prinsip pasar bebas dengan pengawasan atau free market with supervision. Artinya, pemerintah hanya mengawasi saja tidak boleh ikut campur. Pemerintah hanya sebagai penonton. Sedangkan dalam ekonomi Islam masih mengakui pasar bebas tapi harus diatur mekanismenya. Mekanisme tersebut akan diatur oleh lembaga hisbah. Dalam beberapa kasus pasar yang mengalami gejolak yang tidak normal maka pemerintah harus ikut menyelesaikannya. ${ }^{27}$

Umer Chapra menyatakan bahwa sistem pasar bebas telah merealisasikan kemakmuran dalam perekonomian Barat. Akan tetapi, kemakmuran itu tidak menunjukkan hubungan baik antara kepentingan sosial dan individu. ${ }^{28}$ Artinya tidak bisa menciptakan pemerataan kemakmuran.

Sistem pasar bebas telah gagal merealisasikan pemerataan. Kemakmuran yang terjadi tidak berhasil menghapuskan kemiskinan atau pemenuhan kebutuhan pokok bagi setiap orang. Justru ketidakmerataan pendapatan dan keka-

${ }^{23}$ Euis Amalia, Sejarah Pemikiran Ekonomi Islam, h. 70-85.

${ }^{24}$ Euis Amalia, Sejarah Pemikiran Ekonomi Islam, h. 116-118.

${ }^{25}$ Euis Amalia, Sejarah Pemikiran Ekonomi Islam, h. 123-130.

${ }^{26}$ Euis Amalia, Sejarah Pemikiran Ekonomi Islam, h. 192-202 .

${ }^{27}$ Pendapat ini diformulasikan antar pemahaman penulis dengan hasil kuliah bersama Sri Edi Swasono selama bulan Maret 2012.

${ }^{28}$ Umer Chapra, The Fututre of Economics: an Islamic Perspective (Leicester: The Islamic Foundation, 2000), h. 61-63. 
yaan justru semakin meningkat. Di samping itu, tingkat ketidakstabilan ekonomi dan peningkatan jumlah pengangguran telah menambah beban kesulitan bagi si miskin. Ini menunjukkan bahwa efisiensi berkeadilan dan pemerataan masih terabaikan, meskipun pembangunan mengalami kemajuan yang sangat cepat dan pertumbuhan yang luar biasa dalam kekayaan. Tanpa pengawasan dari negara, pendapatan tidak bisa didistribusikan secara merata. ${ }^{29}$ Distribusi pendapatan dan kekayaan yang diawasi oleh negaralah yang akan memberi keadilan ekonomi. ${ }^{30}$

Hal ini menunjukkan bahwa ekonomi Islam mengakui intervensi pemerintah dalam batas-batas tertentu, sebagaimana diterangkan dalam Hadis tentang tiga hal yang tidak boleh dikuasai oleh individu, yaitu: api (sumber energi), rumput (sumber daya alam), dan air.

\section{Aspek Hubungan Antarmitra Bisnis}

Teori ekonomi kapitalis menganggap bahwa orang lain yang sama-sama melakukan kegiatan ekonomi adalah lawan bisnis. Hal ini didasarkan pada filosofi mereka yang berprinsip pada individualisme. Adapun ekonomi Islam mengajarkan bahwa orang lain yang melakukan kegiatan ekonomi bukanlah lawan namun sebagai mitra bisnis. Konsep yang dibangun oleh Islam adalah kesejahteraan bersama, bukan kesejahteraan individu. Sehingga tidak ada saling menzalimi, menipu, curang dan berbuat aniaya terhadap pihak lain. ${ }^{31}$

Konsep nasabah dalam perbankkan juga berbeda. Hubungan antara nasabah peminjam modal dan bank disebut kreditur dan debitur. Hubungan keduanya adalah utang-piutang. Sehingga terbangun hubungan atas bawah. Hak itu berpengaruh pada psikologi peminjam, karena merasa berutang dan harus segera mengembalikan pokok ditambah bunga. Adapun di perbankan syariah, hubungan yang dibangun antara nasabah dengan bank adalah hubungan mitra bisnis. Bank sebagai pemilik modal disebut shâhib al-mâl dan nasabah yang menggunakan dana bank disebut mudhârib. Hubungan mitra bisnis yang diba-

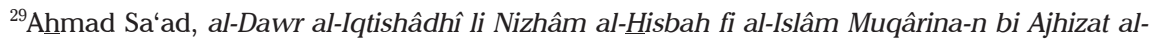
Raqâbah al-Mu' âshirah fi al-Urdûn (Yarmuk: Jâmi‘ah al-Yarmûk, 2002), h. 89.

${ }^{30}$ Shâlih Shâlihî, Makânah Mu'assasah al-Hisbah fî al-Iqtishâd al-Islâmî wa Dawruhâ fî alQadhâ' 'ala al-Fasâd al-Iqtishâdî, (al-Jazâ'ir: Jâmi'ah Sathîf, t.th.), h. 20-22.

${ }^{31}$ Ekonomi kebersamaan dianggap oleh Sri edi Swasono sebagai ekonomi sangat Islami karena mengutamakan ukhuwah. Hal ini sering diutarakan dalam beberapa pertemuan dalam kuliah maupun dituang dalam buku. Lihat, Sri Edi Swasono: Indonesia dan Doktrin Kesejahteraan Sosial dari Klasikal dan Neoklasikal sampai ke The end Of Laissez-Faire, (Jakarta: Perkumpulan Prakarsa, 2010), h. 53 . 
ngun harus saling menguntungkan dan saling membantu untuk kesuksesan usahanya. Sehingga kedua belah pihak bekerjasama membangun ekonomi untuk mencapai kesejahteraan bersama. Pada bank konvensional tujuan utamanya adalah hanya keuntungan materi, sedangkan pada bank syariah selain keuntungan materi juga kebahagian dan ketenangan dunia dan akhirat.

\section{Aspek Hubungan Moneter dan Sektor Riil}

Prinsip yang dianut oleh ekonomi kapitalis adalah ekonomi berbasis keuangan. Hal ini berarti bahwa sektor keuangan terpisah dengan sektor riil. Ekonomi kapitalis yang tujuan utamanya adalah keuntungan tidak peduli dengan sektor riil, sehingga terjadi uang yang beredar lebih banyak dari barang dan jasa yang tersedia. Akibatnya, terjadi penurunan nilai mata uang itu sendiri. Tujuan utama bisnis yang dilakukan dalam ekonomi kapitalis adalah mengeruk keuntungan sebesar-besarnya dengan modal yang sedikit. Apapun yang terjadi modal yang sudah diutangkan harus kembali utuh ditambah bunga. Tidak peduli apakah uang yang dipinjam digunakan untuk keperluan produktif atau konsumtif, yang utama adalah kembalinya modal. Demi mengejar keuntungan tersebut, maka banyak sekali transaksi derivatif yang tujuannya adalah uang berbunga uang. Sistem ekonomi kapitalis telah menciptakan sistem perdagangan dunia yang semu. Total perdagangan dunia yang jumlahnya jutaan dolar Amerika ternyata 95\% terjadi pada perdagangan pasar uang dalam bentuk derivasi keuangan tidak nyata dan tidak ada kaitannya dengan perdagangan soktor riil. Jadi hanya $5 \%$ dari jumlah total peredaran uang bergerak pada sektor riil. ${ }^{32}$

Dikotomi anntara sektor moneter dan sektor riil tidak disadari oleh banyak kalangan. Tokoh-tokoh ekonomi konvensional telah mengakui bahwa antara sektor moneter dan sektor riil tidak ada keterkaitan antara keduanya. ${ }^{33}$ Artinya penambahan uang beredar hanya akan meningkatkan harga saja, tanpa memengaruhi jumlah transaksi riil. Jadi, tidak ada hubungan antara sektor riil dengan sektor moneter, antara keduanya berjalan secara sendiri-sendiri.

Ekonomi kapitalis telah menghasilkan sistem perekonomian yang lebih banyak dikuasai pasar bursa atau modal. Kurang memberikan kontribusi yang cukup nyata terhadap sektor riil. Bahkan, cenderung bersifat semu sehingga pertumbuhan ekonomi yang didorong oleh pasar bursa menjadikan pertum-

\footnotetext{
${ }^{32}$ Veithzal Rivai, "Prospek Lembaga Keuangan Islam di Era Krisis Financial Global Dengan Melaksanakan Sistem Keuangan Islam pada Kekuatan Bisnis \& Pelayanannya dapat Mengatasi Dampak Krisis Finansial Global", Jakarta, 30 Maret 2009, h. 6.

${ }^{33}$ Nopirin, Ekonomi Moneter, (Yogyakarta: BPFE Universitas Gadjah Mada, 1987), h. 67.
} 
buhan ekonomi seperti balon yang setiap saat mudah pecah. Perdagangan yang dijalankan lebih banyak pada transaksi bunga bukan sesuatu yang riil. Tetapi lebih banyak unsur derivatif dari uang sebagai komoditas, yang lebih banyak bersifat spekulatif. Fenomena seperti itulah yang dinamakan dengan bubble economic. Di sisi lain, peredaran uang hanya pada orang-orang tertentu saja. Sedangkan mayoritas masyarkat harus berebut dari bagian yang sedikit.

Berbeda dengan ekonomi Islam, prinsip yang ditanamkan adalah ekonomi yang berbasis sektor riil. Artinya, modal harus berputar dalam bentuk investasi riil untuk mendapatkan keuntungan. Berputarnya keuangan harus diiringi dengan bergeraknya sektor riil. Investasi yang dilakukan harus mampu menciptakan lapangan kerja untuk menggerakkan ekonomi rakyat. Dalam ekonomi Islam tidak dikenal adanya pemisahan antara sektor moneter dan sektor riil. ${ }^{34}$

Sektor keuangan dalam definisi ekonomi Islam diartikan sebagai mekanisme pembiayaan transaksi atau produksi di pasar riil. Perekonomian Islam adalah perekonomian yang berbasis perdagangan. Penghapusan sistem bunga dan penerapan loss and profit sharing merupakan konektor yang akan menghubungkan kedua sektor ini. Keuntungan atau profit yang dibagi merupakan representasi dari hasil usaha di sektor riil. Sebagaimana firman Allah, "Allah menghalalkan jual-beli dan mengharamkan riba" . Ayat tersebut tergambar bahwa transaksi jual-beli atau perdagangan merupakan instrumen yang ditekan-kan dalam ekonomi Islam. Artinya, perekonomian Islam adalah perekonomian riil.

Sistem ekonomi kapitalis menjadikan bunga sebagai jantung dari sektor keuangannya. Berbeda dengan ekonomi Islam, jantung sektor keuangannya adalah sistem bagi-hasil (profit and loss sharing). Dalam ekonomi syariah, jumlah uang yang beredar harus sama banyaknya dengan nilai barang dan jasa dalam perekonomian.

\section{Aspek Sasaran Pembangunan}

Pembangunan ekonomi yang diutamakan dalam sistem ekonomi kapitalis adalah pertumbuhan ekonomi, sehingga tampak bahwa ekonomi dianggap maju jika indokatornya meningkat, seperti: pengangguran menurun, nilai ekspor naik, tingkat inflasi yang bisa dikendalikan, dan GNP-nya naik. Konsep pembangunan ekonomi kapitalis hanya memperhatikan pada wilayah lingkungan fisik saja. Pertumbuhan menurut teori ekonomi kapitalis adalah perkembangan dalam

${ }^{34}$ Ali Sakti, Ekonomi Islam Jawaban atas Kekacauan Ekonomi Modern, (Jakarta: Aqsa Publishing, 2007), h. 49. 
perekonomian yang menyebabkan barang dan jasa yang diproduksi meningkat, yang selanjutnya diiringi dengan peningkatan kemakmuran masyarakat. Tingkat pertumbuhan ekonomi yang dicapai suatu negara diukur dengan perkembangan pendapatan nasional riil yang dicapai oleh suatu negara yaitu produk nasional bruto (PNB) atau produk domestik bruto (PDB).

Ekonomi Islam tidak hanya menekankan pertumbuhan ekonomi, namun juga mengutamakan pemerataan dan keadilan. Hal itu ditegaskan dalam Alquran bahwa harta tidak boleh berputar di kalangan orang-orang kaya saja. Menurut 'Abd Allâh 'Abd al-Husayn al-Tharîqî, pertumbuhan ekonomi tidak sekadar aktivitas produksi material saja. Lebih dari itu, pertumbuhan ekonomi merupakan aktivitas menyeluruh dalam bidang produksi yang terkait erat dengan keadilan distribusi. Pertumbuhan ekonomi bukan hanya diukur dari aspek ekonomi, melainkan aktivitas manusia yang ditujukan untuk pertumbuhan dan kemajuan sisi material dan spiritual manusia sekaligus. ${ }^{35}$

M. A. Mannan menyatakan bahwa konsep pembangunan ekonomi menurut ekonomi pembangunan Islam memiliki keunggulan dibandingkan konsep ekonomi lainya, yakni terletak pada motivasi filosofi pembangunan ekonominya. Motivasi pembangunan dalam Islam, tidak hanya timbul dari masalah ekonomi manusia semata-mata tetapi juga dari tujuan ilahi yang tertera dalam Alquran dan Hadis. ${ }^{36}$

\section{Aspek Mata Uang}

Uang adalah faktor uutama dalam dunia ekonomi. Nilai mata uang yang stabil sangat menentukan pertumbuhan ekonomi. Jika nilai mata uang runtuh maka sendi-sendi ekonomi juga akan mengalami keruntuhan. Walapun masih diperselisihkan, Islam telah menggunakan mata uangnya berupa dinar dan dirham. Dinar dan dirham diakui sebagai mata uang yang tidak terpengaruh secara signifikan jika terjadi inflasi. Dinar dan dirham telah digunakan sebagai mata uang resmi sejak zaman Romawi hingga kejayaan Islam di Turki. Namun, sejak AS menetapkan uang dolarnya sebagai uang dunia, dinar dan dirham mulai hilang dalam kegiatan ekonomi. ${ }^{37}$ Uang kertas yang disebut fiat money telah

35 'Abd Allâh 'Abd al-Husayn al-Tharîqî, al-Iqtishâd al-Islâmî, Ushûluh wa Mubaun wa Ahdaf, (Kuwayt: Dâr al-Nafâ'is, 1999), h. 282.

${ }^{36}$ M. Abdul Mannan, Islamic Economiys, Theory and Practice, terj. M. Nastangin, Teori dan Praktek Ekonomi Islam, (Yogyakarta: Dana Bakti Waqaf, 1997), h. 393-394.

37 Pergantian dinar dan dirham dengan dolar berawal dari konferensi yang diprakarsai oleh Amerika di Bretton Woods pada tahun 1944 yang isinya adalah janji Amerika untuk mendukung uang 
menggantikan dinar dan dirham. Ternyata, uang kertas tersebut membuat ekonomi dunia menjadi hancur dengan sering terjadinya krisis keuangan hampir di setiap negara. Nilai mata uang yang berbasis kertas semakin gari semakin tidak bernilai. Nilai uang satu juta rupiah sekarang lebih rendah dari nilai satu juta setahun kemudian. Hal ini membuktikan bahkan nilai mata uang berbasis kertas tidak bernilai.

Beberapa tokoh ulama salaf dan tokoh ekonom modern menggagas kembalinya penggunaan mata uang berbasis emas dan perak. Ide itu muncul karena kegagalan mata uang kertas dalam mempertahankan nilainya. Inflasi yang terjadi hampir sepanjang masa, menggugah mereka untuk kembali ke mata uang yang nilai intrinsiknya sama dengan barangnya.

Dalam hal pencetakan uang, ekonomi kapitalis tidak mendasarkannya pada sektor riil. Sedangkan ekonomi Islam, pencetakan uang harus didasarkan pada kebutuhan sektor riil. Jika kegiatan sektor riil berjalan, maka uang atau modal baru diciptakan. Berbeda dengan ekonomi kapitalis, uang dicetak untuk menciptakan kerja, sehingga terjadi gelembung ekonomi, di mana uang banyak tapi sepi investasi.

\section{Penutup}

Ekonomi Islam memiliki definisi, filosofi, sejarah, dan ukuran berbeda dengan ekonomi kapitalis. Perbedaan-perbedaan tersebut adalah ciri khusus yang menjadikan ekonomi Islam menjadi jalan lain untuk menciptakan peradaban yang lebih baik. Namun demikian, penerapan ekonomi Islam masih banyak kendala di semua tingkatan, mulai dari pemerintah sebagai pemegang kebijakan hingga mindset masyarakat yang sudah nyaman dengan sistem ekonomi kapitalis. Untuk mengubah pola pikir masyarakat yang sudah terlanjur mendarah daging tentang konsep ekonomi kapitalis dibutuhkan kesabaran dan kegigihan yang kuat. Penerapan ekonomi Islam harus menyeluruh, walaupun dilakukan secara bertahap. Jihad untuk menegakkan teori ekonomi Islam harus dimulai dari sekolah-sekolah dasar hingga perguruan tinggi. Karena selama ini buku-buku pelajaran yang diajarkan adalah teori ekonomi kapitalis. [ ]

dolarnya secara penuh dengan emas yang nilainya setara. Namun janji itu diingkari bahkan tidak lagi mengizinkan mata uang lain disetarakan dengan emas, harus dengan dolar. Hal itu juga diberlakukan kepada negara-negara anggota IMF, termasuk Indonesia. Lihat, Muhaimin Iqbal, Dinarnomics Membangun Keberkahan Usaha dengan Uang yang Adil, (Jakarta: Sinergi Publishing, 2010), Cet. I, h. 106-108. 


\section{Pustaka Acuan}

Al-Qur'ân al-Karîm

Abbas, Anwar, Philopsopy Sistem Ekonomi Islam, Jakarta: 14 Maret 2012.

Abdul Fattah, Dede, Pasar dan Keadilan dalam Perspektif Ekonomi Islam: Analisis Peran Lembaga Hisbah Era Abbasiyah, Jakarta: Gaung Persada Press, 2011.

Al Kaaf, Abdullah Zaky, Ekonomi dalam Perspektif Islam, Bandung: Penerbit Pusataka Setia Bandung, 2002.

Al-Assal, Ahmad Muhammad dan Fathi Ahmad Abdul Karim, Sistem, Prinsip dan tujuan Ekonomi Islam, alih bahasa Imam Saefuddin, Jakarta: CV. Pustaka Setia, 1999.

Amalia, Euis, Sejarah Pemikiran Ekonomi Islam dari Masa Klasik Hingga Kontemporer, Jakarta: Pustaka Asatruss, 2005.

Amin, A. Riawan, Menata Perbankan di Indonesia, Jakarta: UIN Press, 2009.

Tharîqî, al-, 'Abd Allâh 'Abd al-Husayn, Al-Iqtishâd al-Islâmî: Ushûluh wa Mubaun wa Ahdaf, Kuwayt: Dâr al-Nafâ'is, 1999.

Chapra, M. Umer, Islam dan Tantangan Ekonomi, Jakarta: Gema Insani Press, 2000.

Hamidi, M. Luthfi, Gold Dinar Sistem Moneter Global yang Stabil dan Berkeadilan, Jakarta: Senayan Abadi Publishing, 2007.

Iqbal, Muhaimin, Dinarnomics Membangun Keberkahan Usaha dengan Uang yang Adil, Jakarta: Sinergi Publishing, 2010.

Mannan, M. Abdul, Islamic Economiys, Theory and Practice, penerjemah M.

Nastangin, Teori dan Praktek Ekonomi Islam, Yogyakarta: Dana Bakti Waqaf, 1997.

Nopirin, Ekonomi Moneter, Yogyakarta: BPFE Universitas Gadjah Mada, 1987.

Sakti, Ali, Ekonomi Islam Jawaban atas Kekacauan Ekonomi Modern, Jakarta:

Aqsa Publishing, 2007.

Hasan, Surahman Kastin dan Ahmad, Sanep, Ekonomi Islam, Selangor: Dawama Sdn. Bhd, 2005.

Swasono, Sri Edi, Indonesia dan Doktrin Kesejahteraan Sosial dari Klasikal dan

Neoklasikal sampai ke The end of Laissez-Faire, Jakarta: Perkumpulan Prakarsa, 2010.

Ekspose Ekonomi Mewaspadai Globalisasi dan Pasar-Bebas,

Yogyakarta: Pusat Studi Ekonomi Pancasila (Pustep)-UGM, 2010.

, Paradigma Baru ilmu Ekonomi, Jakarta, 28 Februari 2012. 
